\title{
SPECYFIKA POSTAW I ZACHOWAŃ STUDENTÓW CHIŃSKICH JAKO PRZEDSTAWICIELI KULTUR KOLEKTYWNYCH W PERSPEKTYWIE GLOTTODYDAKTYCZNEJ
}

\begin{abstract}
Słowa kluczowe: glottodydaktyka, incydenty krytyczne, kolektywizm, indywidualizm, koncepcja twarzy

Streszczenie. Niniejszy artykuł wpisuje się w krąg rozważań na temat wpływu czynników kulturowo zależnych na proces rozwoju społecznego oraz sposoby funkcjonowania w odmiennym kręgu kulturowym. Stanowi także próbę odpowiedzi na pytanie, w jakim stopniu kultura modeluje interakcje w środowisku nauczania i wpływa na tworzenie wypowiedzi w języku obcym. Punktem odniesienia dla norm społecznych typowych dla szeroko pojętej kultury Zachodu są zasady budowania relacji międzyludzkich w społeczeństwach Azji Wschodniej. Przyjęta perspektywa ma charakter interdyscyplinarny - czerpie przede wszystkim z badań prowadzonych $\mathrm{w}$ dziedzinie psychologii międzykulturowej oraz nauk społecznych, szukając dla nich zastosowania na gruncie glottodydaktyki polonistycznej. Szerzej omówiony został aspekt roli i struktury relacji międzyludzkich opartych na kolektywizmie lub indywidualizmie, koncentrując się na wyłonieniu czynników istotnych z dydaktycznego punktu widzenia. W artykule wykorzystano metodę obserwacji incydentów krytycznych oraz analizę tekstów studentów chińskich uczących się języka polskiego. Przedstawione opisy dowodzą, że czynniki kulturowe mogą prowadzić do nieporozumień w środowisku nauczania i rzutować na rozwój i ocenę umiejętności językowych. Z tego względu kwestią niezwykle istotną jest poszerzanie własnej wiedzy socjokulturowej przez wykładowców języka polskiego, którzy pracują ze studentami pochodzącymi z kultur kolektywnych.
\end{abstract}

\section{WZROST ZAINTERESOWANIA STUDIAMI POLONISTYCZNYMI W CHINACH}

Kształcenie polonistyczne w Chinach ma swoją wieloletnią tradycję. Pierwszy chiński ośrodek, w którym nauczano polszczyzny, świętował w 2019 r. sześćdziesięciopięciolecie swojego istnienia. Na ten rok przypadły także obchody

*adriana.prizel-kania@uj.edu.pl, Uniwersytet Jagielloński, Wydział Polonistyki, Centrum Języka i Kultury Polskiej w Świecie, Katedra Języka Polskiego jako Obcego, ul. Grodzka 64, 31-044 Kraków. 
siedemdziesiątej rocznicy nawiązania stosunków dyplomatycznych między Polską i Chinami. Pierwszy wydział kształcący polonistów na Dalekim Wschodzie nieprzypadkowo został uruchomiony pięć lat później (w 1954 r.) na Pekińskim Uniwersytecie Języków Obcych (BUFS). Od tego czasu wielu studentów chińskich zdobywało w jego murach wiedzę na temat naszej kultury, historii i współczesności oraz doskonaliło umiejętności posługiwania się językiem polskim i thumaczenia polskiej literatury.

Przez ponad 50 lat (do 2009 roku) polonistyka pekińska była jedynym tego rodzaju ośrodkiem uniwersyteckim działającym na terenie Chińskiej Republiki Ludowej. Kolejną uczelnią, na której w 2010 roku uruchomiono studia polonistyczne, był Uniwersytet Pedagogiczny w Harbinie. Następnie, w 2014 roku, powstał Wydział Polonistyki na Kantońskim Uniwersytecie Spraw Międzynarodowych, a rok później otworzono drugi ośrodek kształcenia polonistycznego w Pekinie - Pekiński Uniwersytet Studiów Międzynarodowych (BISU). W 2017 roku została otworzona polonistyka na Szanghajskim Uniwersytecie Studiów Międzynarodowych, będąc piątą w Chinach uczelnią oferującą ten kierunek studiów. W artykule z roku 2018 Mao Rui wymienia już dziesięć ośrodków, a podczas II Ogólnochińskich Warsztatów Glottodydaktycznych, które odbyły się wiosną 2019 roku w Pekinie, zaprezentowanych zostało 13 chińskich uczelni wyższych, na których naucza się języka polskiego. Obecnie na terenie Chińskiej Republiki Ludowej działa 19 takich ośrodków. Część z nich oferuje regularne studia polonistyczne, część - zajęcia z języka polskiego w ramach lektoratu języka obcego ${ }^{1}$. „Takiego szybkiego tempa rozwoju studiów polskich i polonistyk poza Chinami nie odnotował żaden kraj na świecie.” (Rui 2018, s. 58).

Jak można wnioskować ze słów Mao Rui tendencje wzrostowe będą się utrzymywać ze względu na szczególne miejsce i rolę Polski w koncepcji One Belt - One Road (Jeden pas, jeden szlak), będącej obecnie ważnym przedsięwzięciem gospodarczym Chińskiej Republiki Ludowej. Pokłosiem realizacji planu budowy nowego jedwabnego szlaku jest niezwykle dynamiczny rozwój ośrodków oferujących kształcenie polonistyczne na terenie całych Chin.

W związku z rosnącą liczbą studentów chińskich podejmujących studia na wydziałach polonistycznych lub uczących się języka polskiego na lektoratach organizowanych w rodzimych uczelniach coraz więcej młodych Chińczyków przyjeżdża do Polski w ramach wymiany studenckiej, stypendiów, stażów bądź też na studia łączone, których realizacja zakłada dwa lata nauki w uczelni chińskiej, a kolejne dwa lata w Polsce ${ }^{2}$. Chińscy poloniści stanowią zatem coraz większą

\footnotetext{
${ }^{1}$ Dane pochodzą ze strony Instytutu Polskiego w Pekinie; https://instytutpolski.pl/beijing/pl/ nauka-polskiego-w-chinach/ [21.08.2020].

${ }^{2}$ W roku 2019 na Wydziale Polonistyki Uniwersytetu Jagiellońskiego utworzono nowy kierunek studiów pierwszego stopnia „Studia polskie - język, kultura, społeczeństwo”, którego słuchaczami są studenci chińscy. Podobne studia łączone (2 lata edukacji w Chinach i 2 lata edukacji w Polsce) działają także na Uniwersytecie Warszawskim.
} 
grupę studentów w wielu polskich ośrodkach akademickich. Studenci z Chin coraz częściej zatem wchodzą $\mathrm{w}$ grupy zróżnicowane pod względem kulturowym lub tworzą grupy narodowościowo jednolite.

Artykuł ten jest efektem doświadczeń w nauczaniu Chińczyków, poszukiwań wiedzy i badań na temat społeczeństw Azji Wschodniej oraz osobistego zainteresowania kulturą Chin. Do jego napisania doprowadziła obserwacja szeregu incydentów krytycznych, w których ujawniały się istotne różnice w rozumieniu otaczającej nas rzeczywistości oraz fakt, że częstokroć można tę inność w pojmowaniu świata nieumiejętnie zaklasyfikować jako nieporozumienie o charakterze językowym lub błąd interpretacyjny.

\section{OD INCYDENTÓW KRYTYCZNYCH DO REFLEKSJI MIĘDZYKULTUROWEJ}

Każda lekcja języka obcego jest jednocześnie dialogiem o charakterze kulturowym, a w sytuacji zetknięcia $\mathrm{z}$ rozmówcą pochodzącym $\mathrm{z}$ tak odmiennego jak Chiny obszaru kulturowego, wymaga przygotowania ze strony wykładowców odpowiedzialnych za kształcenie językowe oraz wprowadzanie treści socjo- i realioznawczych. Warto zatem zdać sobie sprawę z tej „Inności”, aby odpowiednio przygotować się do wejścia $\mathrm{z}$ nią $\mathrm{w}$ dialog, a także po to, by móc z tego spotkania kultur czerpać jak najwięcej i potrafić zwrócić uwagę na to, co leży u podstaw tej różności, co stanowi jej istotę i podłoże. Warunkami koniecznymi są: zachowanie postawy otwartości i zainteresowania nowymi doświadczeniami, skłonność do relatywizmu własnego kulturowego punktu widzenia oraz związanego z nim systemu wartości, a także umiejętność zdystansowania się wobec konwencjonalnych nastawień do różnic kulturowych, etnicznych, religijnych, czyli chęć przezwyciężania stereotypów (ESOKJ 2003, s. 96).

Sama jednak ciekawość i otwartość może okazać się niewystarczająca - potrzebna jest świadomość i wiedza na temat kulturowych uwarunkowań zachowań społecznych, wyznawanych wartości oraz stylów epistemologicznych - tym bardziej, że różnice w sposobie interpretacji rzeczywistości, zdobywania wiedzy, stylu myślenia i działania są zwykle nieuświadamiane przez obie strony tego dialogu - uczącego się i nauczyciela. Każdy z nas przyjmuje bowiem, że pewne podstawowe zasady tworzenia i utrzymywania relacji są mechanizmami uniwersalnymi, niezależnymi od miejsca urodzenia i sposobu wychowania. Wszyscy jednak patrzymy na świat przez pryzmat naszej kultury, której czynnikiem konstytuującym i jednocześnie kulturowo zależnym jest język. To on strukturyzuje sposób myślenia - widzenia i opisywania rzeczywistości. Co więcej, zanurzeni we własnej kulturze nie dostrzegamy tego, co dla niej typowe, przyj- 
mując zasady w niej obowiązujące za powszechne i naturalne. Kultura rozumiana jest tutaj w kategoriach psychologicznych jako system wartości, norm i skryptów zachowań, charakterystycznych dla poszczególnych grup i narodów, przekazywanych z pokolenia na pokolenia. Wartości w tym przypadku oznaczają to, co jest powszechnie uważane za ważne i wartościowe, normy wskazują kierunek podejmowanych decyzji i zachowań, natomiast skrypty stanowią scenariusze postępowania w danej sytuacji (Boski 2010). Zjawisko interpretowania i oceniania zdarzeń według standardów obowiązujących w kulturze, w której wzrastaliśmy, nazywane jest ślepotą kulturową i nawet rozbudowana świadomość istnienia mechanizmów ślepoty kulturowej nie jest w stanie nas przed nią uchronić. Nas - nauczycieli i naszych studentów.

Warto zatem sięgnąć do psychologii międzykulturowej, która - poszukując psychologicznych wymiarów kultury - dąży do wyjaśniania różnic między ludźmi w zakresie wielorakich zachowań społecznych. „Dysponując tymi wymiarami, badacz [nauczyciel - APK] nie musi już polegać w interpretacji różnic na wrażeniu, anegdocie lub stereotypie, jako że pomiar dostarcza metodologicznego sprawdzianu dla założonych wpływów kultury." (Matsumoto 2001, s. 184, za Boski 2010, s. 45).

Prowadząc zajęcia językowe w grupie, w której są studenci chińscy oraz przedstawiciele szeroko pojmowanej kultury Zachodu, nauczyciel staje się świadkiem (a często i stroną) wielu incydentów krytycznych, które niedoświadczonego pedagoga mogą wprawiać w zdziwienie, czasami zakłopotanie, a nauczyciela-badacza fascynować. Incydenty krytyczne definiujemy tu w kategoriach zakłóceń komunikacyjnych, których przyczyną jest zastosowanie przez jednego z partnerów interakcji odmiennego skryptu kulturowego bądź bezpośrednie przeniesienie norm działania językowego z języka ojczystego do docelowego, co może zostać odebrane jako złamanie pewnej konwencji społecznej bądź językowej, nieznajomość zasad lub nawet pogwałcenie reguł grzeczności (por. Cushner, Brislin 1996, s. 13-14). Zaskoczenie jest większe, ponieważ i burzenie norm, i oburzenie, do którego może to prowadzić, nie są działaniami intencjonalnymi, a wynikają z zastosowania odmiennych kodów kulturowych. Dogłębna i systematyczna analiza zdarzeń krytycznych stanowi cenne narzędzie pozwalające uniknąć tego rodzaju nieporozumień dzięki możliwości przewidywania trudności, które mogą pojawić się w środowisku nauczania (Zarzycka 2010, s. 65) lub przeciwnie - zapobiec incydentom krytycznym w autentycznych sytuacjach komunikacyjnych, planując interakcje obciążone ryzykiem w przestrzeni klasowej.

Znajomość różnic między skryptami kulturowymi pozwoli także nauczycielowi uniknąć sytuacji niezręcznych, lepiej zaplanować przebieg zajęć, odpowiednio dobrać materiały, a przede wszystkim stanowi punkt wyjścia do budowania umiejętności interkulturowych, czyli pośredniczenia pomiędzy kulturą własną a kulturą obcą. 
W niniejszym artykule przedmiotem badań jest struktura relacji międzyludzkich, którymi w kulturze Zachodu i Azji Wschodniej rządzą odmienne reguły3. Różnice w więziach społecznych można charakteryzować poprzez opis kultur kolektywistycznych $\mathrm{w}$ zestawieniu ze społeczeństwami indywidualistycznymi, a także związanej z tym hierarchii społecznej i koncepcji twarzy. Od kilku dziesięcioleci przyglądanie się kulturom ze szczególnym zwróceniem uwagi na obowiązujący w nich rodzaj relacji społecznych stanowi przedmiot dociekań naukowych badaczy z nurtu psychologii międzykulturowej. Badania i refleksje nad sposobem definiowania siebie (własnych celów, wartości, powinności) na tle lub w oderwaniu od danej grupy - poczynając od tej najmniejszej jaką jest rodzina, po ujęcie najszersze rozumiane w kategoriach przynależności narodowej - stanowią główny temat wielu prac naukowych. Punktem odniesienia do przedstawianych w niniejszym artykule przykładów są badania prowadzone przez E. Halla (1984), G. Hofstedego (2001), H. Triandisa (1995) oraz R. Nisbetta (2015), które stanowią niezbędny kontekst teoretyczny dla omawianych incydentów krytycznych i analizy treści nacechowanych kulturowo, pojawiających się w pracach pisemnych i wypowiedziach studentów chińskich.

\section{SPOLECZNA WSPÓŁZALEŻNOŚĆ CZY DĄŻENIE DO WYJĄTKOWOŚCI}

W badaniach holenderskiego psychologa G. Hofstedego (2007) społeczeństwa Azji Wschodniej, a w szczególności Chin, należą do grup o najwyższym wskaźniku na skali indywidualizm-kolektywizm (IDV). Sam badacz definiuje ten wymiar kultury następująco: „Indywidualizm odnosi się do społeczeństwa, w którym więzi między jednostkami są luźne: od każdego oczekuje się, że sam będzie dbał o siebie i swą najbliższą rodzinę. Kolektywizm odnosi się do społeczeństwa, gdzie jednostki od urodzenia przez całe swe życie są zintegrowane z silnymi, spójnymi grupami Swoich, które to grupy zapewniają na stałe ochronę, w zamian za bezwarunkową lojalność." (Hofstede 2001, s. 225). Charakterystyka społeczeństw opartych na współzależności i tych dążących do indywidualizacji jednostki stanowiła także główny przedmiot dociekań E. Halla (1984), prekursora badań w tej dziedzinie, który rozróżnił kultury wysokiego i niskiego kontekstu. H. Triandisa (1995) zajmuje natomiast specyfika postaw

\footnotetext{
${ }^{3}$ Stosując terminy „kultura Zachodu” i „kultura Azji Wschodniej”, używam ich w znaczeniu sugerowanym przez badaczy zajmujących się tą tematyką (Triandis 1995; Hofstede 2007; Nisbett 2015; Boski 2010). Kultura Zachodu dotyczy społeczeństw Europy i Stanów Zjednoczonych, natomiast kultury Azji Wschodniej odnoszą się do społeczeństw Chin, Japonii i Korei Południowej - przy czym kultura chińska będzie miała tu największy zasięg.
} 
i kształtowanie się osobowości w społeczeństwach indywidualistycznych i kolektywistycznych.

Zgodnie z opisem E. Halla przedstawiciele społeczeństw zależnych od kontekstu cenią skromność oraz przedkładają obowiązek nad własne szczęście, a wykonywanie powinności jest zadaniem samonagradzającym się, co w środowisku edukacyjnym przekłada się na pilność, solidność i wytrwałość w nauce. Po drugiej stronie kontinuum - światem ludzi słabo uzależnionych od kontekstu (głównie społeczeństwa Europy Zachodniej i Ameryki Północnej) rządzi potrzeba wyróżniania się, wyrażania własnej opinii, a zapatrzenie w siebie stanowi właściwość kultury Zachodu (Hall 1984).

Do podobnych wniosków prowadzą badania $\mathrm{H}$. Triandisa, który charakteryzuje przedstawicieli kultur kolektywistycznych jako społeczeństwa ceniące dbałość o relacje i odpowiednie zachowanie w określonych relacjach międzyludzkich. W przypadku przedstawicieli kultur współzależnych definiowanie siebie i własnej wartości odbywa się zatem w odniesieniu do pełnionej roli. $Z$ drugiej strony w społeczeństwach indywidualistycznych podkreśla się niezależność i wyjątkowość jednostki, której podstawowym celem jest realizacja własnych planów, dążenie do samorozwoju i osobistego szczęścia. W społeczeństwach indywidualistycznych ważna jest także niezmienna i niezależna od czynników zewnętrznych spójność pomiędzy postawą i zachowaniem, a jej brak określany jest jako hipokryzja (Triandis 1995). Ludzie Zachodu zakładają, że każdy człowiek obdarzony jest zestawem indywidulanych cech, które czynią go wyjątkowym i tę właśnie odrębność należy pielęgnować (Triandis 1995; Nisbett 2015). Zaskoczeniem może zatem być fakt, że ktoś nie chce się wyróżniać, że zamiast podkreślać swoje mocne strony i rozwijać talenty, umniejsza własne umiejętności, nie chcąc wybijać się na tle innych. Za ilustrację tej tezy może posłużyć dość typowa sytuacja, w której nauczyciel doceniając osiągnięcia studentki bądź studenta z Chin, słyszy w odpowiedzi zdanie: „Dziękuję. Muszę pracować więcej. Będę bardziej się starać”, podczas gdy uczący się z kręgu kultury Zachodu najczęściej podziękują za pochwałę, ewentualnie dodatkowo podkreślą swoje wysiłki. To niedocenianie własnych umiejętności jest dla Chińczyków charakterystyczne. W tym kontekście nie należy również spodziewać się ożywionej rozmowy czy rozbudowanych wypowiedzi podczas zajęć poświęconych tematowi zainteresowań, osiągnięć i talentów. Chińczycy rzadko opowiadają o swoich wyjątkowych umiejętnościach, nie chcą zaskakiwać wyszukanymi pasjami bądź uzdolnieniami, jak to bywa w przypadku Europejczyków bądź Amerykanów. Nie chcą bowiem wywyższać się w myśl zasady, że wystajacy kotek zostanie spitowany (Nisbett 2015, s. 50). Ważniejsze niż chęć bycia docenianym jest dążenie do utrzymania harmonijnych relacji z innymi, znalezienie oparcia w ludziach, których cechuje podobieństwo w stylu życia i zachowania. Studiujący w Polsce Chińczycy tworzą zwartą grupę, w obrębie której wspierają się, przekazują sobie informacje, razem uczą się. Jeżeli ktoś spóźnia się na zaję- 
cia (co zdarza się niezwykle rzadko), grupa natychmiast reaguje - kontaktuje się $\mathrm{z}$ danym studentem/ daną studentką, sprawdza, jakie są przyczyny nieobecności i nakreśla sytuację nauczycielowi. Jest to działanie naturalne, związane z poczuciem współodpowiedzialności za wszystkich członków grupy.

W środowisku nauczania postrzeganie siebie przez pryzmat grupy społecznej może także wpływać na sposób wykonywania zadań czy realizację pewnych form wypowiedzi. W pracach studentów chińskich, których celem jest przedstawienie się lub prezentacja innych osób, znajdujemy następujące stwierdzenia: Bardzo lubię spędzać dzień z moją rodzina. Mój ojciec jest bardzo pracowity i często nie jest w domu. On bardzo lubi gotować. Moja mama jest ładna, niska i miła. Razem robimy zakupy. Czuję się dobrze kiedy jesteśmy w domu ${ }^{4}$. Częstokroć proporcje pomiędzy informacjami o sobie oraz na temat innych osób są zaburzone.

Innym przykładem, w którym uwidacznia się istota i waga budowanych relacji, jest wypowiedź jednej ze studentek na temat różnic i podobieństw pomiędzy życiem studenckim w Polsce i w Chinach, w której zawiera się następujący fragment: Nie jestem bardzo specjalna osoba. Lubię ogladać koreańskie seriale i stuchać muzyki. Moje życie w Polsce nie różni się bardzo od życia w Chinach. To samo jest, że mieszkam z Irena. Mieszkamy już razem prawie trzy lata. W Chinach często bylyśmy razem i teraz też. Lubimy razem próbować nowe potrawy i robić zakupy. Zwykle w weekendy zostajemy w pokoju w akademice. Chodzimy do galerii krakowskiej jeden raz w tygodniu. Na uniwersytecie w Chinach uczestniczyłam w stowarzyszeniu wolontariuszy. Często byłam bardzo zajęta, ale byłam szczęśliwa z pracy w wolontariat. To była ważna sprawa. W Chinach często chodzitam z przyjaciótmi - razem jedliśmy i piliśmy. Teraz nie spotykamy się, bo sa $w$ Chinach, ale kontakt dalej jest dobry.

W tym krótkim fragmencie, jak w soczewce, obserwować możemy sposób widzenia rzeczywistości przez pryzmat kontaktów i współzależności od innych ludzi. Podobnym przykładem będzie sposób wykonania zadania egzaminacyjnego, którego polecenia brzmiało następująco: „Razem z koleżanką/ kolegą chcecie wynająć mieszkanie na czas studiów w Polsce. Obejrzyj zdjęcia czterech mieszkań i zdecyduj, która oferta jest najbardziej interesująca”. Do arkusza egzaminacyjnego dołączono fotografie czterech wnętrz. Studentka przyjrzała się pokojom i zaczęła następująco: Wybieram ofertę numer trzy, ponieważ to mieszkanie ma kolor zielony, a moja koleżanka bardzo lubi zielony i na pewno będzie szczęśliwa mieszkać tam. Ona nie lubi nowoczesne wnętrza i dlatego nie wybieram ofertę $d w a \ldots$ Ponownie mamy do czynienia z sytuacją, która jest różna pod względem kulturowym. Wydawać by się także mogło, że studentka nie do końca zrozumia-

${ }^{4}$ Wszystkie przywoływane w artykule fragmenty wypowiedzi ustnych lub pisemnych pochodzą z prac studentów „Studiów polskich - język, kultura, społeczeństwo”, uczących się w Uniwersytecie Jagiellońskim w roku akademickim 2019/2020. We wszystkich tekstach zachowano autentyczny zapis, stąd pojawiające się błędy językowe. 
ła polecenie i zamiast wybierać mieszkanie dla siebie dostosowuje swój wybór do gustu współlokatorki. Nic bardziej mylnego - intencja została zrealizowana poprawnie, ponieważ to właśnie dbałość o zadowolenie koleżanki były bardziej istotne niż własne upodobania.

Innym przykładem jest pisanie charakterystyki. To, z pozoru łatwe, zadanie może nastręczać problemów natury kulturowej. W kulturach Azji Wschodniej cechy charakteru - coś, co dla nas jest niezmienne i niezależne od czynników środowiskowych - związane są bowiem z kontekstem i rolą, w której występujemy. Stąd wypowiedzi typu: on jest bardzo poważny na lekcji, ale w akademiku jest wesoly również można uznać za powszechnie używane w pracach studentów chińskich. Cechy charakteru są ujmowane dynamicznie - mogą ulegać zmianie w zależności od sytuacji i rodzaju zadania. Dowodem na tego rodzaju postrzeganie i opisywanie siebie przez pryzmat roli i w kontekście relacji z innymi ludźmi są badania prowadzone przez R. Nisbetta (2015). Badacz poprosił wybranych Japończyków i Amerykanów, aby opisali siebie niezależnie od kontekstu oraz w określonych ramach sytuacyjnych. Japończykom bardzo trudno było opisać siebie bez kontekstu, natomiast Amerykanów charakteryzowanie siebie w jakimś kontekście wprowadzało w konsternację. Najczęściej pojawiającym się argumentem było stwierdzenie: jestem, kim jestem. W eksperymencie wykazano także, że mówiąc o sobie, Azjaci dwa razy częściej niż Amerykanie wymieniają inne osoby, co potwierdza wcześniej postawione tezy (Nisbett 2015, s. 53). Wiele różnic w postrzeganiu zasad, jakimi powinna kierować się jednostka, zauważyć można także podczas omawiania przymiotników opisujących cechy charakteru. Studenci z Chin poproszeni o zakwalifikowanie takich określeń, jak: asertywny, pewny siebie, oryginalny, ambitny częstokroć uznają te przymioty za negatywne, co może wydać się zaskakujące przedstawicielom innych krajów. Nie wynika to, jak mogłoby się wydawać, z braku zrozumienia danego określenia ${ }^{5}$, a z innego systemu wartości. Dowodem na to jest fakt, że w języku chińskim nie występują takie słowa, jak: 'asertywność' i 'indywidualizm' - a najbliższy im znaczeniowo odpowiednik to 'samolubstwo' (Nisbett 2015, s. 51). Asertywność, tak charakterystyczna dla kultur, w których ceniona jest niezależność i indywidualizm, w Azji Wschodniej jest postrzegana jako brak dojrzałości, bowiem w społeczeństwach opartych na współzależności istotniejsza niż podkreślanie własnego zdania jest umiejętność wpasowania się w układ relacji z innymi. „Dany człowiek nie jest bowiem w pierwszym rzędzie jednostką, indywidualnością, lecz członkiem grupy i musi się kierować kodeksem postępowania ściśle związanym z odgrywaną rolą." (Weggel 2006, s. 37).

${ }^{5}$ Incydent krytyczny, który potwierdza tę tezę miał miejsce podczas praktyk zawodowych słuchaczy studiów podyplomowych na kierunku Nauczanie języka polskiego jako obcego i drugiego, w trakcie których prowadząca zajęcia studentka wielokrotnie i z pewnym zniecierpliwieniem powtarzała i tłumaczyła znaczenie słowa ,asertywny”, próbując przekonać studentów chińskich do tego, że bycie asertywnym jest cechą bardzo ważną i pożądaną. 
Za pewien przejaw utożsamiania się z odgrywaną rolą można także uznać przyjmowanie polskich imion przez studentów z Chin ${ }^{6}$. Można to interpretować jako ukłon w stosunku do polskich nauczycieli, dla których zapamiętanie i wymowa prawdziwych imion może być trudna, niemniej jednak stosowanie polskiego odpowiednika imienia wykracza często poza przestrzeń klasy i zaczyna funkcjonować w dużo szerszym kontekście społecznym. Jest czymś więcej niż zastępczym imieniem - to drugie imię, określające konkretną rolę.

\section{MIEJSCE I ROLA W UKLADZIE SPOLECZNYM}

„W Azji Wschodniej przyjmuje się, że zasady obowiązujące w relacjach nie są uniwersalne, ale konkretne, jasno określone, związane z rolą i miejscem" (Nisbett 2015, s. 50). Z pełnieniem określonych ról wiąże się stosowne zachowanie $\mathrm{w}$ różnych kontekstach społecznych, także edukacyjnym. Pojmowanie roli ucznia, a następnie studenta, ukształtowane zostaje poprzez doświadczenie wczesnoszkolne oraz związane z nauką w gimnazjum, liceum i na jednej z chińskich uczelni. Sposób kształcenia i system edukacji w Chinach realizuje zadania społeczne i przygotowuje do życia $\mathrm{w}$ grupie, w harmonii z innymi ludźmi. Metody nauczania opierają się na wartościach spajających społeczeństwo chińskie, a główne zasady regulujące sposób kształcenia nawiązują do filozofii konfucjańskiej. $Z$ perspektywy relacji międzyludzkich istotne jest zwrócenie uwagi na hierarchiczny stosunek w relacjach uczeń-nauczyciel. P. Boski nazywa styl nauczania (oraz wiążące się z nim sposoby uczenia się) obowiązujący w Chinach 'modelem konfucjańskim' w opozycji do typowego dla kultur Zachodu 'stylu sokratejskiego' (Boski 2010, s. 365). Zgodnie z systemem konfucjańskim wiedzę należy przyjmować z szacunkiem dla niej samej i osób ją przekazujących. $Z$ tego względu nauczyciel jest autorytetem, ,mistrzem, któremu okazuje się niesłabnący szacunek" (tamże), a studenci dokładają wszelkich starań, by wypełnić wszystkie polecenia nauczyciela - liczą także na jego pomoc i wsparcie w procesie kształcenia, przyjmują niemalże bezwarunkowo każde zadanie, nie wyrażając nigdy przy tym niezadowolenia.

Doświadczenie pracy z grupą chińską wydaje się zatem zadaniem wdzięcznym, ale i niezwykle odpowiedzialnym. $Z$ rozmów z nauczycielami, którzy pracują ze studentami z Azji Wschodniej wynika, że w tej relacji wykładowcy wchodzą w rolę opiekuńcze znacznie częściej niż w przypadku studentów z innych krajów. Odczuwają bowiem takową konieczność, a często także jakąs niepisaną, naturalną potrzebę.

${ }^{6}$ Polskie imiona przyjmują także studenci z Korei Południowej, zdecydowanie rzadziej studenci japońscy. 
W kręgu cywilizacji Zachodu relacje hierarchiczne wiążą się raczej z odczuwaniem dyskomfortu - ludzie preferują pozycje równorzędne, a w sytuacji konieczności zachowania hierarchii - wolą przyjmować rolę nadrzędną. Wyrazem tego jest możliwość zwracania się do wykładowcy za pomocą bezpośrednich zwrotów w niektórych krajach Europy Zachodniej oraz w Stanach Zjednoczonych. W Polsce środowisko akademickie pozostaje mocno ustrukturyzowane - niemniej jednak edukacja opiera się na innych zasadach, z których najważniejszą stanowi kształcenie ludzi niezależnych, myślących krytycznie, nastawionych na samodzielne zdobywanie wiedzy. Nauczyciel w tym modelu wskazuje jedynie drogę i możliwości samorozwoju. Odczuwana intuicyjnie przez polskich wykładowców inność relacji nauczyciela ze studentami z krajów azjatyckich i z Europy Zachodniej, podbudowana wiedzą na temat różnych zasad kierujących kształceniem, może stanowić istotny aspekt modelowania relacji w środowisku nauczania. Nadrzędnym celem, ale i największym wyzwaniem dla wykładowców pracujących z Chińczykami, jest wykorzystanie dotychczasowych, opartych na konfucjanizmie, doświadczeń edukacyjnych studentów oraz wprowadzanie nowych metod poszukiwania wiedzy, bliższych stylowi sokratejskiemu.

\section{KONCEPCJA TWARZY}

Ostatnim pojęciem, nierozerwanie związanym z kwestiami poruszonymi w poprzednich akapitach, jest koncepcja twarzy, którą trafnie opisuje O. Weggel słowami: „Główną regułę gry obowiązującą w Chinach można by sformułować w sposób następujący: daj każdemu jego twarz, nie pozwól nikomu stracić twarzy, dbaj o zachowanie własnej twarzy." (Weggel 2006, s. 36). Zachowanie twarzy jest pojęciem z kręgu kultur opartych na wspólnocie i odgrywa fundamentalną rolę w budowaniu relacji międzyludzkich oraz każdym akcie komunikacji interpersonalnej. Reguły związane z zachowaniem twarzy mają swoje źródło w filozofii konfucjańskiej i wiążą się z dbałością o drugiego człowieka, wykluczając możliwość postawienia go w sytuacji trudnej, kłopotliwej, narażającej na śmieszność lub utratę dobrego imienia. Zgodnie z konfucjańską koncepcją społeczeństwa człowiek jest kształtowany poprzez odpowiednie wychowanie, życie w harmonijnej wspólnocie i relacje społeczne, a jego wartość dla tego społeczeństwa określa miejsce zajmowane w hierarchii oraz obowiązki, jakie mu powierzono (Xinzhong Yao 2009). Pojęcie twarzy można definiować w kilku wymiarach, a w zrozumieniu jego złożoności pomocna okazuje się analiza językowa. W pracy chińskiego językoznawcy H. Donga czytamy, że w języku chińskim funkcjonują dwa określenia oznaczające 'twarz' - 'miànzi' i 'liăn'. Podczas gdy 'miànzi' jest używane w znaczeniu metaforycznym jako obraz publicznego statusu i pozycji społecznej, 
'liăn' podkreśla szacunek, jakim jednostka jest obdarzona przez wspólnotę w zamian za respektowanie jej praw i zasad moralnych (Hongyuan Dong 2014). Określenie 'liăn' bliższe jest zatem kwestiom związanym z wewnętrznym kodeksem moralnym, charakterem, osobowością, a 'miànzi' dotyczyć będzie funkcjonowania jednostki w szerszym, zewnętrznym kontekście. Należy jednak zwrócić uwagę, że oba te wyrażenia wzajemnie się przenikają i niezmiennie określają miejsce jednostki w grupie społecznej. Tłumaczenie frazy „mieć twarz” i „stracić twarz” można by zatem rozpatrywać w dwóch kontekstach. Po pierwsze, jako utratę bądź zyskanie określonej pozycji w hierarchii społecznej, a wraz z nią należnego szacunku; po drugie, jako zachowanie lub utratę zaufania innych ludzi ze względu na niewłaściwe działania. Jak podkreśla Hongyuan Dong, koncepcja twarzy jest na tyle istotna ze względów kulturowych, że - ukuta przez i na potrzeby anglojęzycznych Chińczyków zamieszkujących na terenie Stanów Zjednoczonych - posiada swój odpowiednik w języku angielskim (lose face, save face).

W języku chińskim „twarz” jest zatem pojęciem dynamicznym - można ją komuś dać, ale i można ją stracić. Nieodpowiednie wywiązywanie się z obowiązków przynależnych do roli grozi ,utratą twarzy”. Z tego względu studenci chińscy dokładają wszelkich starań, by wypełnić swoje zadanie, nie sprawić zawodu nauczycielowi i opanować materiał na oczekiwanym poziomie. Do ciekawych wniosków może prowadzić obserwacja sytuacji, w których student bądź studentka z Chin nie zna odpowiedzi na zadane podczas zajęć pytanie. Najczęściej w jednej chwili inne osoby z grupy przejmują inicjatywę i odpowiadają na pytanie nauczyciela bądź tłumaczą zapytanej/zapytanemu treść zadania, udzielając przy tym odpowiednich wskazówek - wszystko po to, by nie narazić na szwank „twarzy” koleżanki/kolegi. Na podobne wsparcie może także liczyć nauczyciel. Pracując ze studentami chińskimi oraz z grupami mieszanymi, w których znaczną część stanowili Chińczycy, przeprowadziłam kilka podobnych eksperymentów, które polegały na tym, że prosiłam studentów o rozwiązywanie zadań na rozumienie ze słuchu, które zostały już wypełnione na lekcji tydzień wcześniej. Stosowałam przy tym to samo wprowadzenie do nagrania, ten sam komentarz, ten sam sposób objaśniania nowego słownictwa. Obserwowałam konsternację pojawiającą się na twarzach studentów z Chin, którzy spoglądali po sobie, czasami porównywali otrzymany materiał z wcześniejszym, nic jednak nie mówiąc, nie zaburzając toku zajęć. Jeżeli w grupie byli studenci z innych krajów (najczęściej z Ukrainy), niemal natychmiast informowali mnie, że proponowane zadania zostały już wykonane. Nigdy jednak nie byli to studenci chińscy. Co więcej - w grupie w całości chińskiej nikt nigdy nie zwrócił mi uwagi, a kiedy wreszcie zapytałam, czy przypadkiem nie powtarzamy materiału, który już był, studenci zawstydzeni potakiwali głowami, znajdując się w trudnej sytuacji bycia świadkami zdarzenia, w której twarz nauczyciela doznała uszczerbku. Warto także wiedzieć, że pytanie, które często pada z ust nauczyciela „Czy wszystko jest jasne? Czy wszystko Państwo 
rozumieją?", u studentów z Chin zwykle spotka się z odpowiedzią twierdzącą, podczas gdy potem można zaobserwować, że jednak formuła zadania lub treść prezentowanego tekstu przysparzają im trudności. Przyznanie się do niewiedzy obciążone jest także ryzykiem naruszenia studenckiej twarzy.

Dla porównania w języku polskim związek frazeologiczny 'stracić twarz' wiązany jest z utratą honoru, godności, dobrego imienia, najczęściej ze względu na nieetyczne, nieakceptowane działania. Jest zatem konstruktem kojarzonym z moralnością i etyką, bliższym chińskiemu 'liăn'. 'Miànzi', czyli twarz społeczną, miejsce w hierarchii, traktujemy jako odgrywaną rolę, której nie łączymy z naszą osobowością, cechami charakteru - tracąc pracę, nie wypełniając obowiązków żony, męża, szefa, ucznia nie tracimy własnej godności, która pozostaje niezależna od struktury relacji społecznych. Większą wagę przywiązujemy do możliwości bycia niezależnym, do nieulegania naciskom grupy i presjom społecznym. Możliwość wygłaszania własnego zdania, posiadania indywidualnych przekonań - nawet jeśli mogą one ranić innych - wyznaczają często granice naszej wolności i psychicznego komfortu - podobnie jak ,zachowanie twarzy” wyznacza granice godności naszego rozmówcy wychowanego w kulturze, w której współzależność i harmonia społeczna są głównymi wyznacznikami relacji międzyludzkich.

\section{PODSUMOWANIE}

Praca z grupami zróżnicowanymi kulturowo wymaga od nauczyciela odpowiedniego przygotowania. Przytoczone opisy i przykłady pokazują bowiem, jak mocno kulturowe postrzeganie roli i wagi relacji międzyludzkich wpływa na konstrukcję i treść wypowiedzi studentów oraz realizację zadań językowych. Świadomość istnienia tego rodzaju zależności jest bardzo istotna, ponieważ nauczyciele /egzaminatorzy, oceniając prace studentów (np. w ramach egzaminów końcowych lub certyfikatowych), zobowiązani są wziąć pod uwagę takie kryteria jak: poprawność wykonania zadania, wyznaczniki formalne pracy (np. charakterystyki) oraz treść wypowiedzi. Jak wykazano w przykładach, nieznajomość uwarunkowań kulturowych może - niesłusznie - prowadzić do obniżenia punktacji w tych kategoriach i niewłaściwej oceny kompetencji językowych. Warto także budować świadomość odmienności kulturowych u studentów z Azji Wschodniej poprzez odpowiednie przygotowanie programów kształcenia z zakresu wiedzy o społeczeństwie polskim, które w wymiarze indywidualizm-kolektywizm zajmuje pozycję bliższą zachodniemu sposobowi myślenia i działania niż kultury o wysokich wskaźnikach współzależności społecznych.

Opisane w niniejszym artykule doświadczenia podkreślają istotną rolę odmienności o charakterze kulturowym, które manifestują się w drobnych incyden- 
tach krytycznych, czasami niezauważalnych, a jakże istotnych w środowisku edukacyjnym. Ich analiza w odniesieniu do szeroko opisywanych w literaturze badań z zakresu etnografii, nauk społecznych, a przede wszystkim z kręgu psychologii międzykulturowej, których namiastka została zaprezentowana w artykule, pozwala nauczycielowi: po pierwsze lepiej poznać swoich studentów, a po drugie - co bardzo cenne - przyglądać się fenomenom własnej kultury w odniesieniu do reguł rządzących światem społeczeństw kolektywnych. Z tego względu skrypty kulturowe, którymi podążamy i którym ulegamy oraz incydenty krytyczne, które przykuwają nasza uwagę, powinny stać się przedmiotem zainteresowania, refleksji i dyskusji w środowisku glottodydaktycznym.

\section{BIBLIOGRAFIA}

Boski P., 2010, Kulturowe ramy zachowań społecznych. Podręcznik psychologii międzykulturowej. Warszawa.

Cushner H., Brislin R.W., 1996, Intercultural interactions: A practical guide, Londyn-Nowe Delhi.

ESOKJ, Europejski system opisu ksztatcenia językowego - uczenie się, nauczanie, ocenianie, 2003, Warszawa.

Gut A., Wilczewski M., 2015, Porównawcze badania kognitywne (O wpływie czynników kulturowo zależnych na poznanie społeczne), w: K. Morita (red.), Spotkania Polonistyk Trzech Krajów - Chiny, Korea, Japonia, rocznik 2014/2015, Tokio, s. 115-134.

Hall E., 1984, Poza kultura, Warszawa.

Hall E., 2009, Ukryty wymiar kultury, Warszawa.

Hofstede G., 2001, Cultures Consequences. Comparing values, behaviors, institutions and organizations across nations, Londyn-Nowe Delhi.

Hofstede G., 2007, Kultury i organizacje, Warszawa.

Hongyuan Dong, 2014, A History of the Chinese Language, Routledge.

Li Yinan, 2017, Dydaktyka polonistyczna wobec inicjatywy Jeden pas, jeden szlak: program i metody, w: Mao Jinhui (red.), Spotkania Polonistyk Trzech Krajów - Chiny, Korea, Japonia, rocznik 2016/2017, Kanton, s. 387-398.

Malejka J., 2008, Potomkowie smoka o sobie samych, czyli o autostereotypie Chińczyków, „Postscriptum Polonistyczne", nr 1 (1), s. 207-225.

Nisbett R.E., 2010, Inteligencja. Sposoby oddziaływania na IQ. Dlaczego tak ważne sa szkoła i kultura, Sopot.

Nisbett R.E., 2015, Geografia myślenia. Dlaczego ludzie Wschodu i Zachodu myśla inaczej?, Sopot.

Rui M., 2018, Chińscy studenci o rocznych stażach językowych w Polsce, „Kwartalnik Polonicum”, nr 30, s. 57-66.

Triandis H.C., 1995, Individualism \& collectivism, Boulder.

Weggel O., 2006, Chiny, Warszawa.

Xinzhong Yao, 2009, Konfucjanizm. Wprowadzenie, Kraków.

Zarzycka G., 2010, Incydenty krytyczne, czyli najtrudniejsze doświadczenia słuchaczy Studium Języka Polskiego dla Cudzoziemców UŁ, ,Acta Universitatis Lodziensis. Kształcenie Polonistyczne Cudzoziemców", t. 17, G. Zarzycka, G. Rudziński (red.), s. 63-76. 


\title{
Adriana Prizel-Kania
}

\section{ATTITUDES AND BEHAVIORS OF CHINESE STUDENTS AS REPRESENTATIVES OF COLLECTIVE CULTURES - THE GLOTTODIDACTIC PERSPECTIVE} students

Keywords: foreign language teaching and learning, collectivism, individualism, Chinese

\begin{abstract}
This article is a contribution to the study of the influence of culture-specific factors on social development as well as on ways of acquiring and processing information. It is also an attempt to answer the question to what extent culture models interactions in the teaching and learning environment and determines the ways in which knowledge is acquired. The aim of the paper is to present the extent to which the rules of social behavior and relations between people are shaped by environmental factors and what is the influence and involvement of cultural differences in learning and teaching environment.

The main issue presented in this paper reflects the discussion focused on the role of social relations in Chinese culture, and reveal some studies conducted so far in the field of social sciences and psychology. Its perspective draws upon research conducted in intercultural psychology. This paper provides a review of the main findings concerning the influence of the cultural syndromes of individualism and collectivism on the interactions in the educational environment. The primary goal is to describe the process of the language education of Chinese students in Polish studies by describing and analyzing critical incidents and students' utterances in Polish.
\end{abstract}

